\title{
ROMARCHITE, HYDROROMARCHITE AND ABHURITE FORMED DURING THE CORROSION OF PEWTER ARTIFACTS FROM THE QUEEN ANNE'S REVENGE (1718)
}

\author{
Stacie E. DUNKLE, JAmES R. CRAIG ${ }^{\S}$ AND J. Donald RIMSTIDT \\ Department of Geological Sciences, Virginia Polytechnic and State University, Blacksburg, Virginia 24061-0420, U.S.A.
}

WAYNE R. LUSARDI II

Underwater Archaeology Branch, North Carolina Department of Cultural Resources, Institute of Marine Sciences, 3431 Arendell Street, Morehead City, North Carolina 28557, U.S.A.

\begin{abstract}
Pewter, a tin-rich alloy, has been widely used for ornamental and utilitarian purposes for the last 400 years because it is durable, relatively easily worked, resistant to corrosion, and similar to silver in appearance. Pewter plates and implements have been recovered and examined from what is believed to be the wreck site of the Queen Anne's Revenge, flagship of the pirate Blackbeard, that sank near Beaufort, North Carolina in 1718. All of the pewter artifacts from the site display a surface veneer of corrosion products and may be viewed as experiments on tin corrosion that have been continuously in operation for more than 280 years. Mineralogical examination of the pewter samples has revealed that the corrosion products are composed of romarchite $(\mathrm{SnO})$, hydroromarchite $\left[\mathrm{Sn}_{3} \mathrm{O}_{2}(\mathrm{OH})_{2}\right]$, and abhurite $\left[\mathrm{Sn}_{21} \mathrm{Cl}_{16}(\mathrm{OH})_{14} \mathrm{O}_{6}\right]$. The corrosion generally develops in crudely concentric layers, with an inner layer of abhurite in contact with the pewter; the overlying outer layers consist of romarchite and hydroromarchite. Romarchite, hydroromarchite, and abhurite occur as irregular grains and laths up to 100 micrometers in length. Abhurite also occurs as masses of equant grains with abundant small inclusions of residual pewter. Thermodynamic considerations reveal that romarchite may be a metastable phase, and is present as the result of sluggish kinetics in the process of the formation of cassiterite $\left(\mathrm{SnO}_{2}\right)$, the most stable tin oxide in most natural environments. Observation and identification of these phases will be useful in understanding the stability of tin in the weathering environment and the nature of the metal's corrosion products.
\end{abstract}

Keywords: romarchite, hydroromarchite, abhurite, tin oxide, pewter, corrosion, Queen Anne's Revenge, Blackbeard, metal artifacts, North Carolina.

\section{SOMMAIRE}

L'utilisation d'alliages d'étain a été répandu au cours des 400 dernières années dans les applications ornamentales et utilitaires à cause de leur durabilité, la facilité avec laquelle on peut les travailler, leur résistance à la corrosion, et leur ressemblance à l'argent. Des assiettes et des outils en étain ont été récupérés et examinés d'une épave qui serait celle du Queen Anne's Revenge, navire major du pirate Blackbeard, qui a fait naufrage près de Beaufort, en Caroline du Nord en 1718. Tous les artéfacts en étain provenant de ce site ont un placage de produits de corrosion; on peut ainsi les considérer comme témoins d'une expérience en corrosion de l'étain qui dure depuis plus de 280 ans. Un examen minéralogique de ces échantillons d'étain a révélé la nature de ces produits de corrosion: ils contiennent romarchite $(\mathrm{SnO})$, hydroromarchite $\left[\mathrm{Sn}_{3} \mathrm{O}_{2}(\mathrm{OH})_{2}\right]$, et abhurite $\left[\mathrm{Sn}_{21} \mathrm{Cl}_{16}(\mathrm{OH})_{14} \mathrm{O}_{6}\right] . \mathrm{La}$ corrosion se développe en général en couches à peu près concentriques, avec une couche interne d'abhurite en contact avec l'étain; les couches externes contiennent romarchite et hydroromarchite. Romarchite, hydroromarchite, et abhurite se présentent en grains irréguliers et en tablettes atteignant $100 \mu \mathrm{m}$ en longueur. L'abhurite se présente aussi en masses de grains équidimensionnels avec de nombreuses petites inclusions de l'étain original. D'après les considérations thermodynamiques, la romarchite pourrait être métastable, et serait présente à cause de la cinétique lente du processus de formation de la cassitérite $\left(\mathrm{SnO}_{2}\right)$, le produit d'oxydation le plus stable dans la plupart des milieux naturels. L'observation et l'identification de ces phases seront utiles pour bien comprendre la stabilité de l'étain dans des milieux de météorisation et la nature des produits de corrosion de ce métal.

(Traduit par la Rédaction)

Mots-clés: romarchite, hydroromarchite, abhurite, oxyde d'étain, étain, corrosion, Queen Anne's Revenge, Blackbeard, artéfacts de métaux, Caroline du Nord.

\$ Present address: QAR Project, c/o IMS, 3431 Arendell Street, Morehead City, North Carolina 28557, U.S.A. E-mail address: jrcraig@vt.edu

II Present address: Office of the State Archaeologist, Thunder Bay NMS/UP, 145 Water Street, Alpena, Michigan 49707, U.S.A. 


\section{INTRODUCTION}

For more than ten thousand years, humans have used metals to create both utilitarian and ornamental implements. These implements now provide a rich legacy of artifacts ranging from jewelry to tools and weapons that provide insight into past cultures. Most metallic items suffer some corrosion over time, usually as a result of oxidation in air or water. Corrosion is nature's reclamation of the pure metals back into more stable phases that are commonly similar to the ore minerals from which the metals were originally refined. The corrosion phases are often considered nuisances that form at the expense of the underlying metal, destroying or obscuring surface features. Although this may be true, the corrosion phases are extremely beneficial in that they often provide protection, or passivation, for the artifact by forming layers that shield the remaining metal and thus retard destruction. The corrosion layers can thus provide durable, and in some cases impenetrable membranes that protect the underlying metal from further interaction with corrosive elements. The corrosion products that form, oxides, hydroxides, carbonates, sulfides and sulfates, are dependent upon the initial metals present and the environmental conditions under which the artifacts were buried or submerged. A study of corrosion phases is valuable in interpreting the underlying metallic material and environment of corrosion, and may provide valuable information for determining the best means of preservation or restoration of the artifact. We focus here on pewter artifacts recovered from the Queen Anne's Revenge, which was destroyed in 1718 at Beaufort Inlet, North Carolina.

\section{BACKGROUND INFORMATION}

Pewter implements, made of a tin-rich alloy, have been used for more than 3,500 years. The earliest pewter artifact, found in a grave, is attributed to the XVIIIth Dynasty (1580-1350 B.C.) of Abydos, Egypt (Hatcher $\&$ Barker 1974). Pewter was found to be durable, to be relatively easily worked, to be resistant to corrosion, and to resemble silver in appearance; therefore it was widely used and is commonly found in archeological sites. A wide diversity of alloys are considered to fall under the term "pewter", all containing large amounts of tin and varying amounts of lead, copper, antimony, zinc, bismuth or other hardening metals (Hatcher \& Barker 1974). Traditionally, the corrosion materials that form on pewter artifacts in seawater were assumed to be the tin oxide cassiterite $\left(\mathrm{SnO}_{2}\right)$ (North 1987), but recent discoveries have contradicted this assumption. Organ \& Mandarino (1971) reported the discovery of corrosion phases on a tin pannikin that had remained submerged in fresh water at Boundary Falls, Winnipeg River, Ontario, for approximately 150 years. On the basis of $\mathrm{X}$-ray powder-diffraction data, compared with those of synthetic $\mathrm{SnO}$ and $\mathrm{Sn}_{3} \mathrm{O}_{2}(\mathrm{OH})_{2}$, they characterized the two phases and proposed the mineral names romarchite and hydroromarchite, respectively, for them. Their report, unfortunately, consisted only of a brief abstract and contained no illustrations. At the time of the present study (much of it in the form of S. Dunkle's thesis), the report of Organ \& Mandarino (1971) constituted the best information available on these minerals. Subsequent to completion of our study and submission of this manuscript, Ramik et al. (2003) were able to complete their study, which considerably expanded the information available on romarchite and hydroromarchite. We were pleased to delay final revision and return of this manuscript so that the Ramik et al. (2003) paper could appear as a companion paper. Those authors have uncovered a larger list of natural sites where romarchite occurs than was known to us. We refer the reader to their paper for additional data.

Chung et al. (1997) detected romarchite using X-ray diffraction in an investigation of a film of pure tin in air and oxygen. They reported that $\mathrm{SnO}$ was the initial tin phase to form by oxidation, but that it subsequently transformed into $\mathrm{SnO}_{2}$. Williams et al. (1998) reported $\mathrm{X}$-ray-diffraction evidence for the presence of romarchite in black surface residue on ancient Chinese bronze mirrors, but were unable to provide visual evidence. Matzko et al. (1985) named and described the tin oxyhydroxychloride mineral abhurite $\left[\mathrm{Sn}_{21} \mathrm{Cl}_{16}(\mathrm{OH})_{14} \mathrm{O}_{6}\right]$ that had formed on tin ingots submerged in the Red Sea, north of Jiddah, Saudi Arabia for about 100 years. They described the mineral as forming platy, fragile, six-sided crystals averaging $1.5 \mathrm{~mm}$ in diameter. The crystal structure of synthetic equivalents of romarchite and hydroromarchite has been refined respectively by $a b$ initio calculations (Wilson et al. 1996) and Rietveld analysis (Abrahams et al. 1996). Some additional localities for the tin corrosion phase are given in Ramik et al. (2003). The only reported illustrations of abhurite were provided by Matzo et al. (1985), whereas romarchite and hydroromarchite had never been illustrated in the literature prior to this and the accompanying manuscript. Hence, the nature and stability of tin corrosion minerals are neither well documented nor understood; analysis of pewter archeological artifacts may provide further insight into corrosion processes and may prove useful in archeological conservation.

\section{SCOPE OF THE STUdY}

In this paper, we report on the corrosion of pewter artifacts recovered from the wreck site of Queen Anne's Revenge, flagship of the renowned pirate Blackbeard (Lusardi 2000, Lawrence \& Wilde-Ramsing 2001). The ship was destroyed by wave action and storms after becoming lodged on a sand bar in Beaufort Inlet, North Carolina, U.S.A. in June 1718 (Fig. 1). The wreck was discovered during a magnetometer survey in 1996 after hurricanes Bertha and Fran removed some of the sand covering the remains. Many pewter artifacts have been 


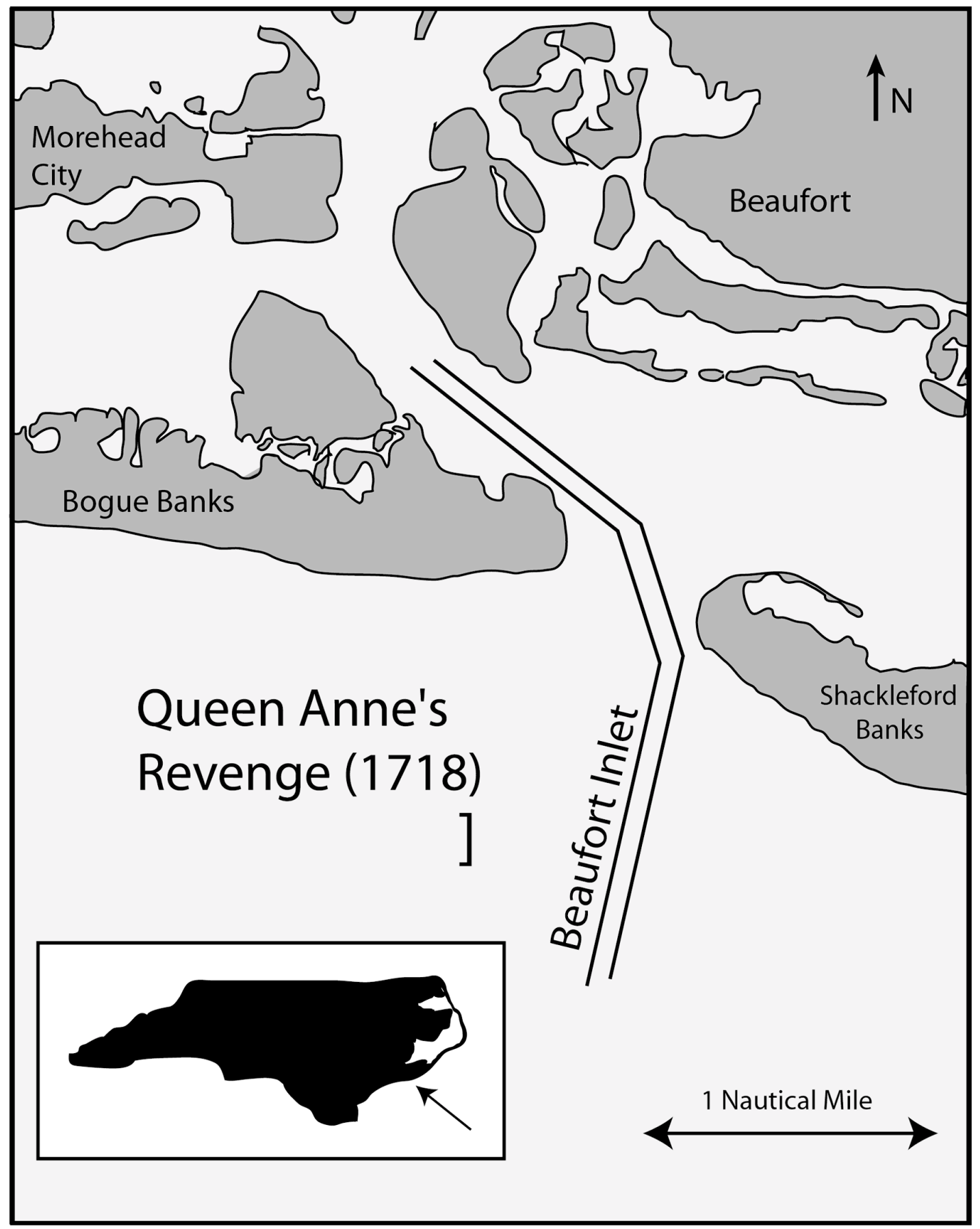

FIG. 1. Map showing modern wreck site of the Queen Anne's Revenge (1718). 


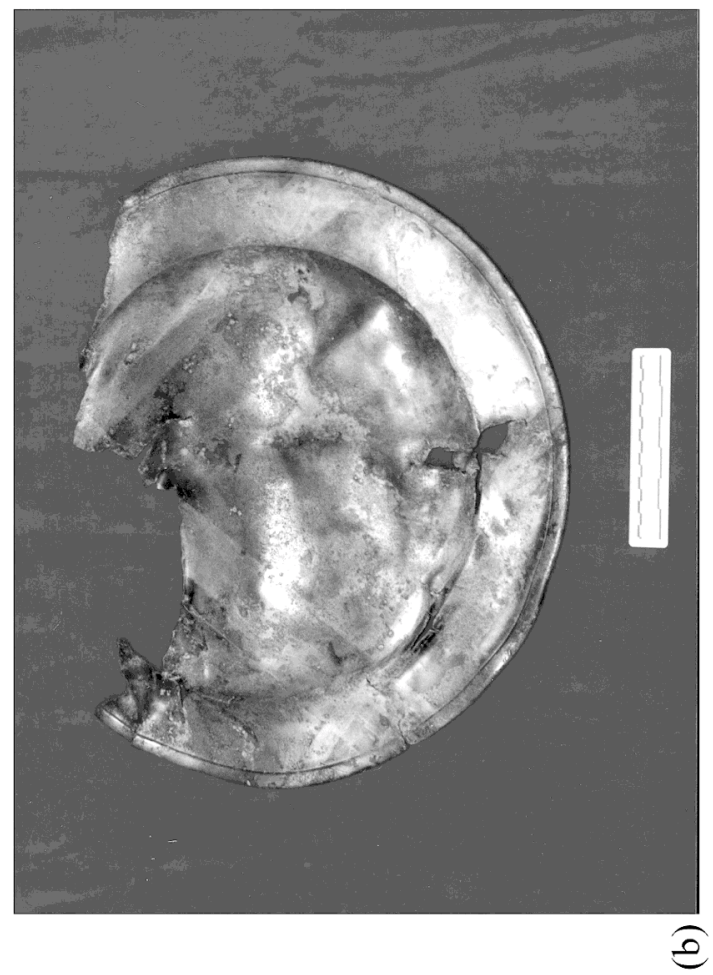

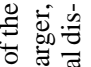

든

डิ

泮

要

ङ

可

要过

政

ड 5

赵

도

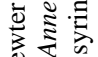

ก ₹

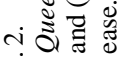

它
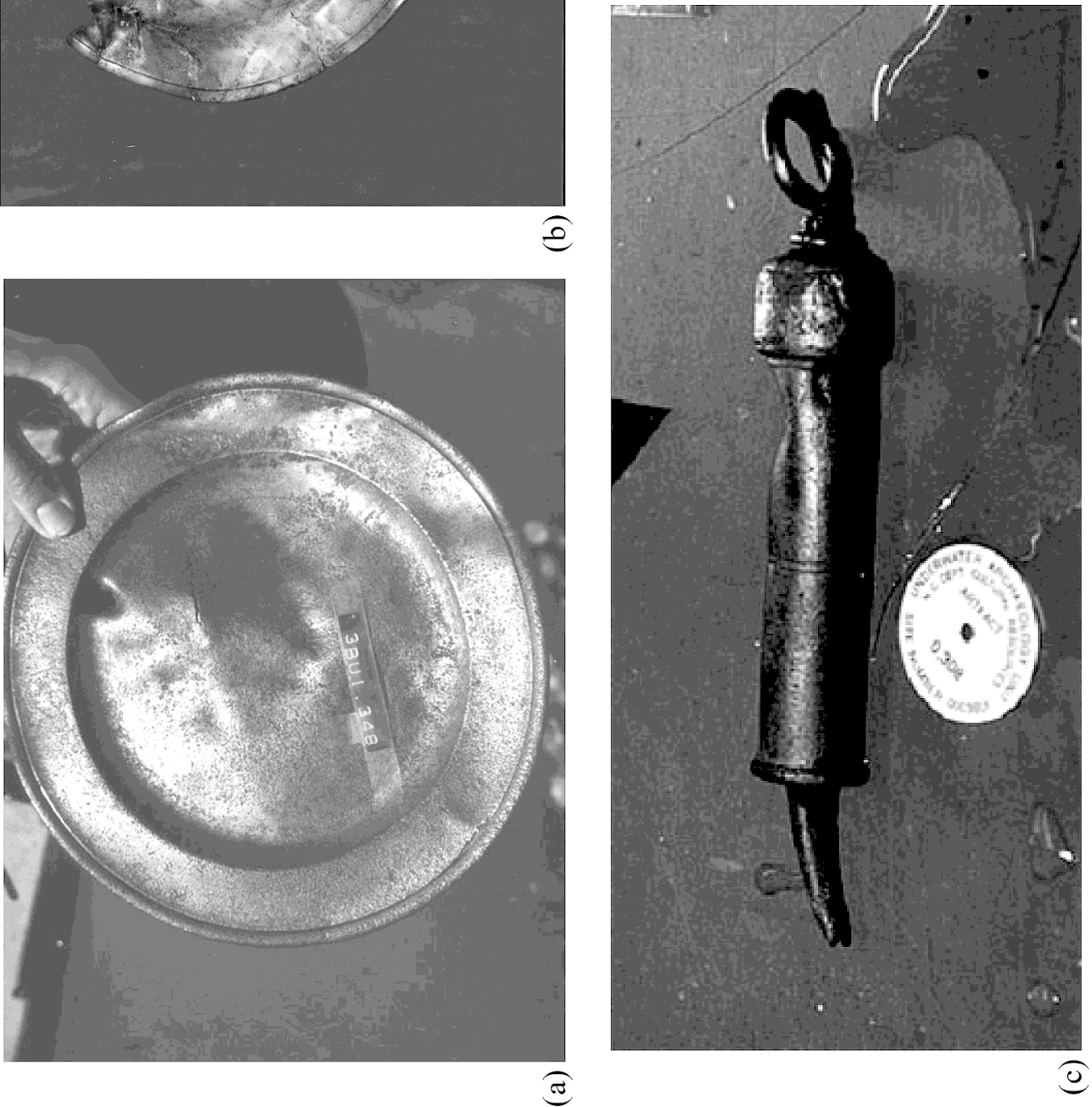
recovered, including a syringe, a spoon and a number of large plates and dishes (Fig. 2) (Craig et al. 2001). This study, part of the first author's thesis (Dunkle 2002), deals with the mineralogy and chemistry of the corrosion products that have formed on the surfaces of these artifacts.

Six samples were examined in this study (Table 1). The samples were buried in offshore fine sands and silts of coastal North Carolina for approximately 280 years. The corrosion environment varied from oxidizing seawater conditions, as evidenced by the formation of oxides and hydroxides, to sulfur-rich reducing conditions, demonstrated by the presence of sulfide minerals (Craig et al. 2001) and the preservation of organic matter, including portions of the ship's wooden hull (Lusardi 2000).

\section{ANALysis of SAMPLES}

The specimens examined in this study were taken as small but representative fragments (approximately 2 to $5 \mathrm{~mm}$ in length) of corroded material from pewter artifacts. The specimens were mounted in a cold-setting EPOFIX epoxy; after hardening, these epoxy plugs were ground and polished to expose a cross section of the pewter artifact and corrosion products using methods described in Craig \& Vaughan (1994). General textural examination was carried out using standard reflectedlight microscopy and a Camscan II scanning electron microscope (SEM); back-scattered electron images, based upon differences in average atomic weight, were found to be particularly useful in deciphering subtle textures. Individual phases were analyzed using a Cameca SX-50 electron microprobe operated at an accelerating voltage of $15 \mathrm{kV}$, a beam current of $20 \mathrm{nA}$, and a beam diameter of $1 \mu \mathrm{m}$. These data were used not only to determine the exact chemical makeup of the phases, but also to create maps to examine the distribution of elements in the uncorroded metal. Limited X-ray powderdiffraction data were collected using a Scintag XDS2000 powder diffractometer.

TABLE 1. DESCRIPTION OF ARTIFACTS, ALLOYS AND CORROSION PRODUCTS ON THE SIX PEWTER ARTIFACTS FROM THE QUEEN ANNE'S REVENGE (1718)

\begin{tabular}{|c|c|c|c|c|c|}
\hline \multicolumn{3}{|c|}{ Artifact summary } & \multicolumn{3}{|c|}{ Minerals identified } \\
\hline Artifact & Type & $\begin{array}{l}\text { Alloying } \\
\text { metals }\end{array}$ & Abhurite & Romarchite & $\begin{array}{l}\text { Hydro- } \\
\text { romarchite }\end{array}$ \\
\hline $\begin{array}{l}271.000 \mathrm{~A} \\
350.001 \\
351.001 \\
128.000 \\
271.000 \mathrm{~B}^{*} \\
457.000\end{array}$ & $\begin{array}{l}\text { plate } \\
\text { charger } \\
\text { charger } \\
\text { charger } \\
\text { charger } \\
\text { unknown }\end{array}$ & $\begin{array}{l}\mathrm{Cu}, \mathrm{Fe}, \mathrm{As} \\
\mathrm{Cu}, \mathrm{Fe}, \mathrm{Pb} \\
\mathrm{Cu}, \mathrm{Fe} \\
\mathrm{Cu}, \mathrm{Fe}, \mathrm{As} \\
\mathrm{Cu}, \mathrm{Fe} \\
\mathrm{Cu}, \mathrm{Fe}, \mathrm{Pb}\end{array}$ & $\begin{array}{l}a \\
\text { a } \\
\text { a } \\
\text { a }\end{array}$ & $\begin{array}{l}\square \\
\square \\
\square \\
\square\end{array}$ & $\begin{array}{l}\text { a } \\
\text { a }\end{array}$ \\
\hline
\end{tabular}

* This sample had undergone cleaning, which apparently removed the encrusting corrosion-induced layers. A corrosion chip from the same specimen $(271.000 \mathrm{~A})$ contained all three of the tin-corrosion minerals.

\section{REsUlts}

Optical and electron-microprobe analyses of the uncorroded pewter reveal that most artifacts are composed of nearly pure tin. Some samples, however, contain small inclusions that are copper-rich (up to $21 \mathrm{wt} . \%$ $\mathrm{Cu}$; Fig. 3). Others contain small inclusions that are ironenriched (up to $20 \mathrm{wt}$ \% Fe), or even consist of iron arsenide (equivalent to FeAs, westerfeldite). The copper inclusions are irregular to lath-like and 1 to $30 \mu \mathrm{m}$ across, whereas the iron and iron arsenides display subhedral to euhedral crystal forms and are up to $50 \mu \mathrm{m}$ across. Trace amounts of lead were observed in two samples. Results of spot analyses of these inclusions are presented in Table 2. A bulk analysis of the pewter artifacts reveals an average composition of 96 to $98 \%$ tin (by weight), with nearly all of the remainder being copper.

Crystals of tin corrosion minerals can be seen on the surface of most pewter artifacts (Fig. 4). In cross-section, it is apparent that the corrosion of pewter results in the progressive development of enclosing zones of oxide and hydroxide phases, as illustrated in Figure 5. Spot analyses reveal the presence of three tin-oxide corrosion minerals: abhurite $\left[\mathrm{Sn}_{21} \mathrm{Cl}_{16}(\mathrm{OH})_{14} \mathrm{O}_{6}\right]$, romarchite $(\mathrm{SnO})$ and hydroromarchite $\left[\mathrm{Sn}_{3} \mathrm{O}_{2}(\mathrm{OH})_{2}\right]$ (Table 2). The corrosion occurs in a concentric fashion from the contact with the outside environment to the inner metal. These corrosion layers vary from $10 \mu \mathrm{m}$ to $2 \mathrm{~mm}$ in thickness. Most commonly, the outer layer is made of romarchite and hydroromarchite, whereas the inner layer is abhurite. The romarchite and hydroromarchite occur as irregular grains or laths up to $100 \mu \mathrm{m}$ in length. The abhurite occurs in massive layers (Fig. 5a) or in thin plates (Fig. 5b). A tin sulfide mineral, believed to be herzenbergite $(\mathrm{SnS})$, was also observed in material from the shipwreck (Fig. 6) (Craig et al. 2001). This mineral, observed on contents from inside the pewter syringe, formed as the tin reacted with sulfur, most likely present as a result of bacteria using sulfate as a terminal acceptor of electrons in this reduced environment.

$\mathrm{X}$-ray-diffraction analysis, using $\mathrm{Ni}$-filtered $\mathrm{Cu} K \alpha$ radiation, was attempted using ground-up material from the surface of the pewter artifacts. The following spacings, in $\AA$, of the reflections (and relative intensities) were: 3.00 (10), 2.70 (2.7), 1.80 (3.5), 1.61 (2) and 1.49 (1.6). These match the data for romarchite reported by Organ \& Mandarino (1971) and Ramik et al. (2003). Subsequent to completion of our study, Andrew C. Roberts of the Geological Survey of Canada kindly conducted microdiffraction analysis of some samples of pewter-corrosion products from Queen Anne's Revenge artifacts and confirmed the presence of romarchite and hydroromarchite. 


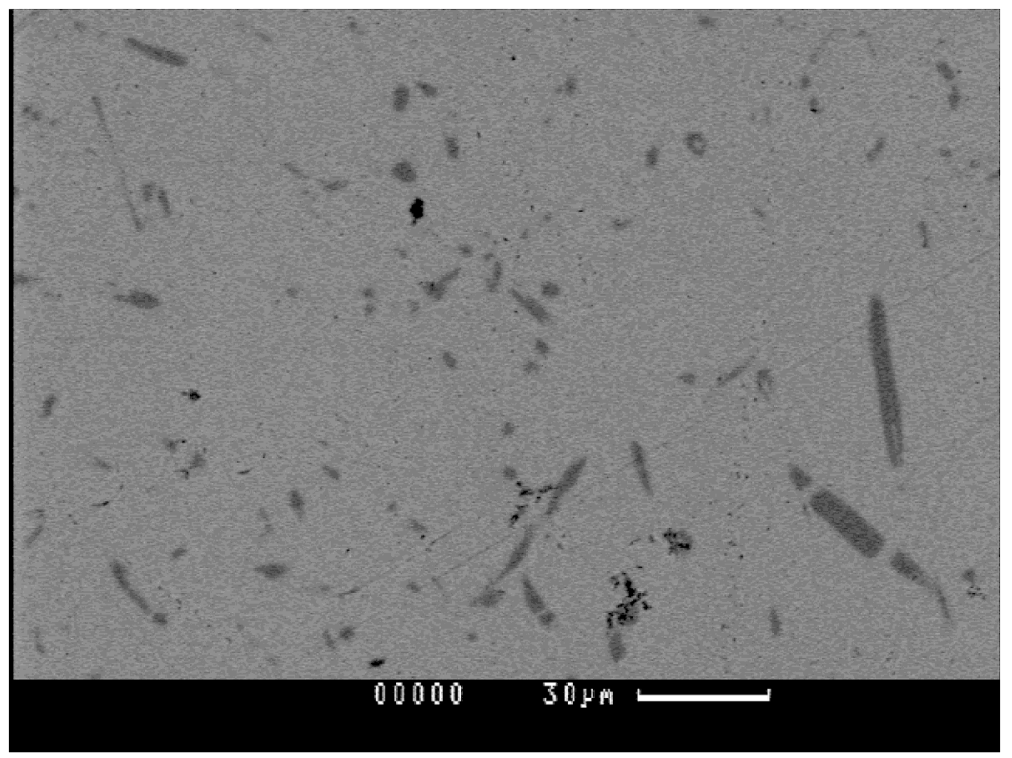

FIG. 3. Back-scattered-electron image of a polished surface of pewter from the Queen Anne's Revenge (1718) (FN-340). The small, dark irregular blebs are areas of high concentration of copper in a matrix of nearly pure tin. Scale bar: $30 \mu \mathrm{m}$.

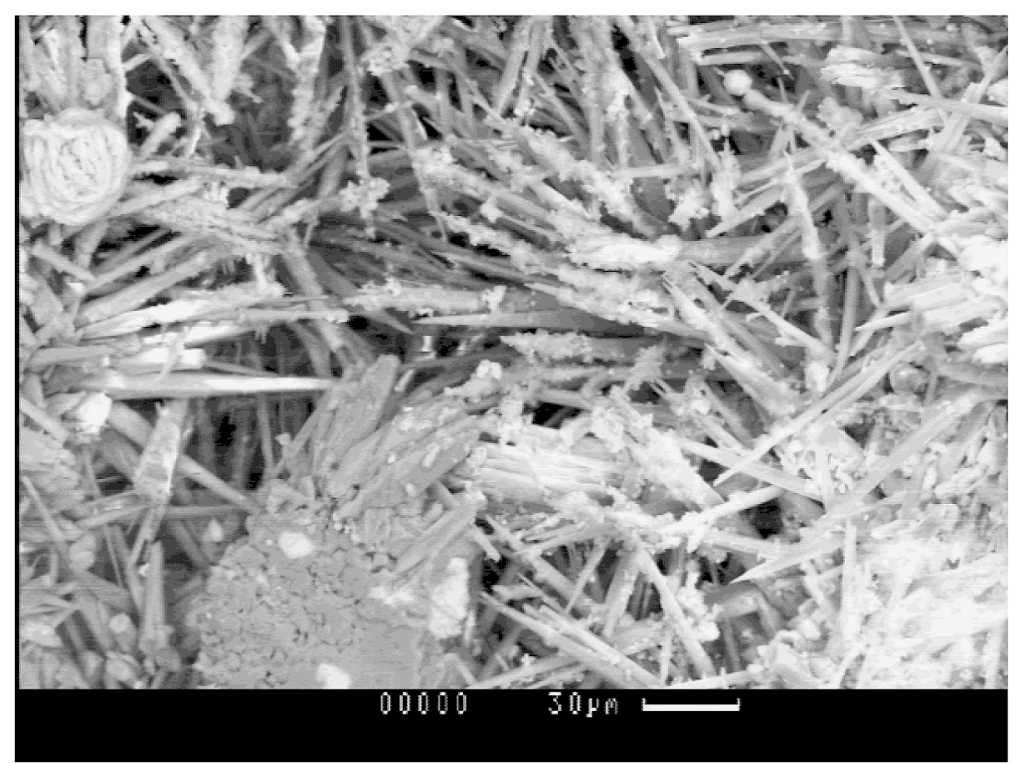

FIG. 4. Needles of romarchite (SnO) developed on the surface of a pewter charger (FN350). The crystals are on the outermost surface of the corrosion products, approximately $0.5 \mathrm{~mm}$ away from what remains of the original pewter. Scale bar: $30 \mu \mathrm{m}$. 
TABLE 2. REPRESENTATIVE CHEMICAL COMPOSITION OF TIN-CORROSION PIIASES ON PEWTER ARTIFACTS FROM THE QUEEN ANNE'S REVENGE (1718)

\begin{tabular}{|c|c|c|c|c|c|c|}
\hline \multicolumn{7}{|c|}{ Pewter: tin matrix } \\
\hline $\mathrm{Sn}$ & $\mathrm{Cl}$ & As & $\mathrm{Cu}$ & $\mathrm{Fe}$ & $\mathrm{Pb}$ & Total \\
\hline 99.65 & 0.01 & 0.01 & 0.12 & 0.04 & 0.19 & 100.02 \\
\hline 98.88 & 0.01 & 0.02 & 0.06 & 0.00 & 0.00 & 98.98 \\
\hline 98.78 & 0.01 & 0.00 & 0.13 & 0.00 & 0.08 & 99.01 \\
\hline 98.94 & 0.00 & 0.00 & 0.05 & 0.01 & 0.00 & 99.00 \\
\hline 98.72 & 0.01 & 0.01 & 0.00 & 0.02 & 0.07 & 98.84 \\
\hline 96.95 & 0.06 & 0.00 & 0.23 & 3.14 & 0.00 & 100.36 \\
\hline \multicolumn{7}{|c|}{ Pewter: inclusions in tin matrix } \\
\hline $\mathrm{Sn}$ & $\mathrm{Cl}$ & As & $\mathrm{Cu}$ & $\mathrm{Fe}$ & $\mathrm{Pb}$ & Total \\
\hline 90.07 & 0.03 & 0.02 & 0.08 & 12.08 & 0.02 & 102.29 \\
\hline 83.23 & 0.01 & 0.01 & 0.24 & 20.04 & 0.00 & 103.53 \\
\hline 83.52 & 0.01 & 0.01 & 0.19 & 19.83 & 0.01 & 103.57 \\
\hline 4.69 & 0.02 & 53.56 & 0.07 & 42.79 & 0.00 & 101.13 \\
\hline 1.41 & 0.01 & 56.10 & 0.04 & 45.95 & 0.15 & 103.65 \\
\hline 70.81 & 0.48 & 0.27 & 21.43 & 0.07 & 0.28 & 93.33 \\
\hline
\end{tabular}

Abhurite, $\mathrm{Sn}_{21} \mathrm{Cl}_{16}(\mathrm{OH})_{14} \mathrm{O}_{6}$

$\begin{array}{cccccccccc}\mathrm{Sn} & \mathrm{Cl} & \mathrm{As} & \mathrm{Cu} & \mathrm{Fe} & \mathrm{Pb} & \mathrm{O} & \text { Subtotal } & \mathrm{H}_{2} \mathrm{O} & \text { Total } \\ 74.65 & 14.86 & 0.00 & 0.00 & 0.00 & 0.00 & 6.71 & 96.22 & 3.78 & 100.00 \\ 75.16 & 13.52 & 0.02 & 0.25 & 0.00 & 0.01 & 7.15 & 96.12 & 3.78 & 99.90 \\ 73.53 & 15.78 & 0.03 & 0.04 & 0.02 & 0.00 & 6.38 & 95.78 & 3.78 & 99.56 \\ 74.67 & 13.90 & 0.01 & 0.07 & 0.05 & 0.00 & 6.96 & 95.66 & 3.78 & 99.44 \\ 75.26 & 13.28 & 0.02 & 0.09 & 0.04 & 0.03 & 7.19 & 95.91 & 3.78 & 99.69 \\ 72.64 & 17.06 & 0.00 & 0.00 & 0.00 & 0.00 & 5.94 & 95.65 & 3.78 & 99.43 \\ 75.08 & 13.29 & 0.05 & 0.03 & 0.00 & 0.00 & 7.15 & 95.59 & 3.78 & 99.37\end{array}$

Romarchite, SnO

$\begin{array}{cccccccr}\text { Sn } & \mathrm{Cl} & \mathrm{As} & \mathrm{Cu} & \mathrm{Fe} & \mathrm{Pb} & \mathrm{O} & \text { Total } \\ & & & & & & & \\ 88.12 & 0.00 & 0.00 & 0.00 & 0.00 & 0.00 & 11.88 & 100.00 \\ 87.59 & 0.03 & 0.02 & 0.08 & 0.01 & 0.20 & 11.85 & 99.77 \\ 88.28 & 0.16 & 0.00 & 0.16 & 0.00 & 0.00 & 11.90 & 100.50 \\ 87.58 & 0.83 & 0.01 & 0.01 & 0.05 & 0.09 & 11.64 & 100.20 \\ 87.47 & 0.21 & 0.03 & 0.09 & 0.00 & 0.09 & 11.78 & 99.67 \\ 87.03 & 0.21 & 0.00 & 0.56 & 0.00 & 0.08 & 11.83 & 99.71 \\ 89.39 & 0.18 & 0.00 & 0.01 & 0.01 & 0.00 & 12.02 & 101.61 \\ 87.80 & 0.17 & 0.00 & 0.14 & 0.08 & 0.00 & 11.86 & 100.05\end{array}$

Hydroromarchite, $\mathrm{Sn}_{3} \mathrm{O}_{2}(\mathrm{OH})_{2}$

$\begin{array}{cccccccccc}\mathrm{Sn} & \mathrm{Cl} & \mathrm{As} & \mathrm{Cu} & \mathrm{Fe} & \mathrm{Pb} & \mathrm{O} & \text { Subtotal } & \mathrm{H}_{2} \mathrm{O} & \text { Total } \\ & & & & & & & & & \\ 84.36 & 0.00 & 0.00 & 0.00 & 0.00 & 0.00 & 11.37 & 95.73 & 4.27 & 100.00 \\ 82.99 & 0.41 & 0.05 & 1.13 & 0.05 & 0.04 & 11.41 & 96.09 & 4.27 & 100.36 \\ 84.88 & 0.52 & 0.00 & 0.08 & 0.03 & 0.00 & 11.35 & 96.86 & 4.27 & 101.13 \\ 84.81 & 0.27 & 0.02 & 0.00 & 0.24 & 0.05 & 11.45 & 96.83 & 4.27 & 101.10 \\ 84.95 & 0.39 & 0.00 & 0.17 & 0.05 & 0.00 & 11.42 & 96.97 & 4.27 & 101.24 \\ 82.28 & 0.27 & 0.00 & 0.54 & 0.05 & 0.00 & 11.18 & 94.32 & 4.27 & 98.59 \\ 85.61 & 0.22 & 0.00 & 0.09 & 0.00 & 0.04 & 11.52 & 97.47 & 4.27 & 101.74\end{array}$

The analytical data were collected using a Cameca SX-50 electron mictoprobe (reported in weight percent). Ideal elemental weight percents of constituents in the (reported in weight percent). Ideal elemental weight percents of constituents in the
minerals are shown in italics. The weight percent of oxygen cannot be measured by minerals are shown in italics. The weight percent of oxygen cannot be measured by
the etectron microprobe and is therefore based upon charge neutrality and the assumed the electron microprobe and is therefore based upon charge neutrality and the assumed
valence of the cations present in the mineral. Also, the ideal weight percent of $\mathrm{H}_{2} \mathrm{O}$ is added to the hydrous minerals.

\section{Discussion}

The same corrosion mineralogy formed on all pewter samples regardless of the concentration of copper, iron and iron arsenide within the tin matrix, as long as the artifact was corroding in oxidizing conditions (Fig. 3 ). We thus contend that romarchite, hydroromarchite and abhurite form universally during tin corrosion in seawater regardless of the composition of the original pewter artifact. Textural analysis using reflected light microscopy and back-scattered electron images permits a preliminary assessment to be made concerning the order of formation of tin-rich corrosion minerals (Fig. 5). Abhurite generally occurs adjacent to the uncorroded metal and still contains inclusions of uncorroded tin within it; therefore it is most likely the first corrosion-induced phase to form in seawater. Over time, the abhurite seems to recrystallize to romarchite and hydroromarchite upon loss of chlorine. Cassiterite, previously believed to be the most common corrosioninduced oxide mineral of tin, was not unequivocally confirmed on any of the Queen Anne's Revenge (1718) samples. The absence of cassiterite cannot be explained thermodynamically, and therefore may be a result of sluggish kinetics. The stability of tin oxides and dissolved tin species was discussed by Edwards et al. (1992) and Séby et al. (2001). The Eh-pH conditions present in seawater and marine sediments fall within the stability field of cassiterite at a dissolved tin activity of $10^{-10}$ (Fig. 7). Romarchite does not appear on the diagram in Figure 8 because a solution does not become saturated with $\mathrm{Sn}(\mathrm{OH})_{2}{ }^{0}$ species until an activity of dissolved tin of $10^{-6.73}$ is reached at a $\mathrm{pH}$ between 4 and 9.7 (Fig. 9). Figure 9 illustrates that the $\mathrm{Sn}(\mathrm{OH})_{2}{ }^{0}$ field shrinks with increased activity of dissolved tin at the expense of the growing fields of $\mathrm{SnO}_{2}$, stable at higher $\mathrm{Eh}$, and $\mathrm{Sn}^{0}$, stable at lower Eh. Our thermodynamic calculations from data presented in Séby et al. (2001) show that the $\mathrm{Sn}^{0}$ field and the $\mathrm{SnO}_{2}$ (s) field converge at an activity of $10^{-6.59}$, suggesting that romarchite is stable over a range in activity of dissolved tin from $10^{-6.73}$ to $10^{-6.59}$. It is likely that this range is within the error of the data used to make these calculations. Although the activity of dissolved tin is rarely high enough for romarchite to form in the natural environment, it is possible that within the pore spaces adjacent to a corroding pewter artifact, these high activities could occur. Because the stability range of romarchite is so small and the ambient conditions to which the samples were exposed varied with time, it is quite possible that romarchite is a thermodynamically stable phase. However, it is possible to assume that it could form metastably and persist during the 280 year interval that we are considering. If true, we expect that romarchite will eventually recrystallize to form cassiterite. Because romarchite has never been observed in nature other than on corroded tin materials, it is possible that metallic tin is a required precursor for its formation. The near-absence of native tin in the natural environment suggests that human intervention may be necessary for the formation of romarchite.

\section{Conclusions}

Pewter has been used to construct implements for over 3,500 years and thus provides a rich legacy of archeological artifacts. Pewter artifacts from the Queen Anne's Revenge (1718) provide approximately 280year-long experiments revealing the metal's reaction to 

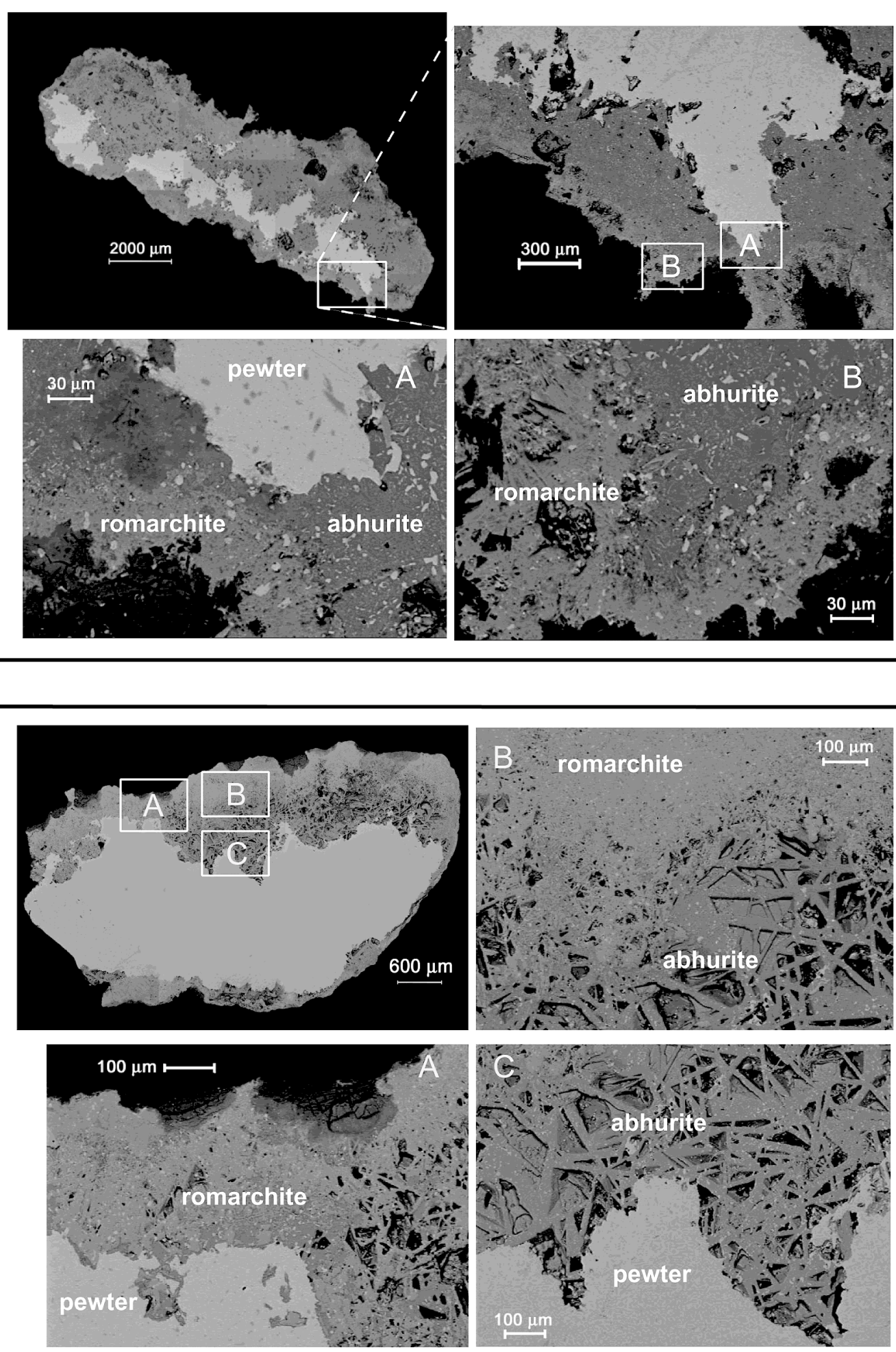

b 


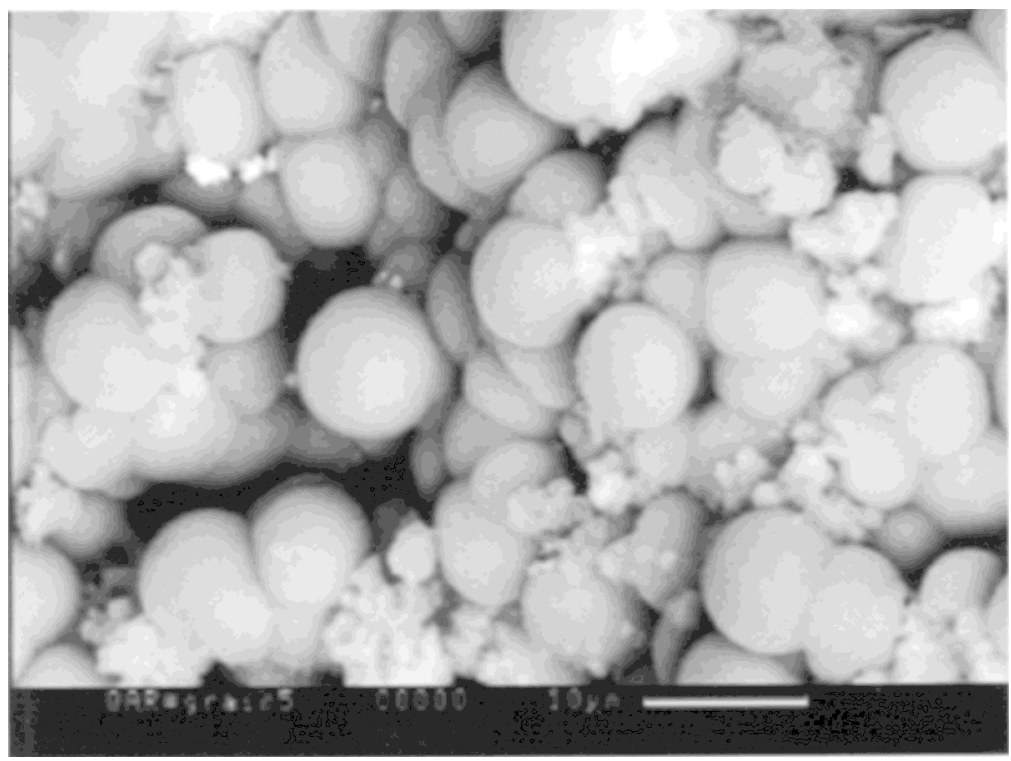

FIG. 6. Herzenbergite, SnS, formed within the pewter syringe. Scale bar: $10 \mu \mathrm{m}$.

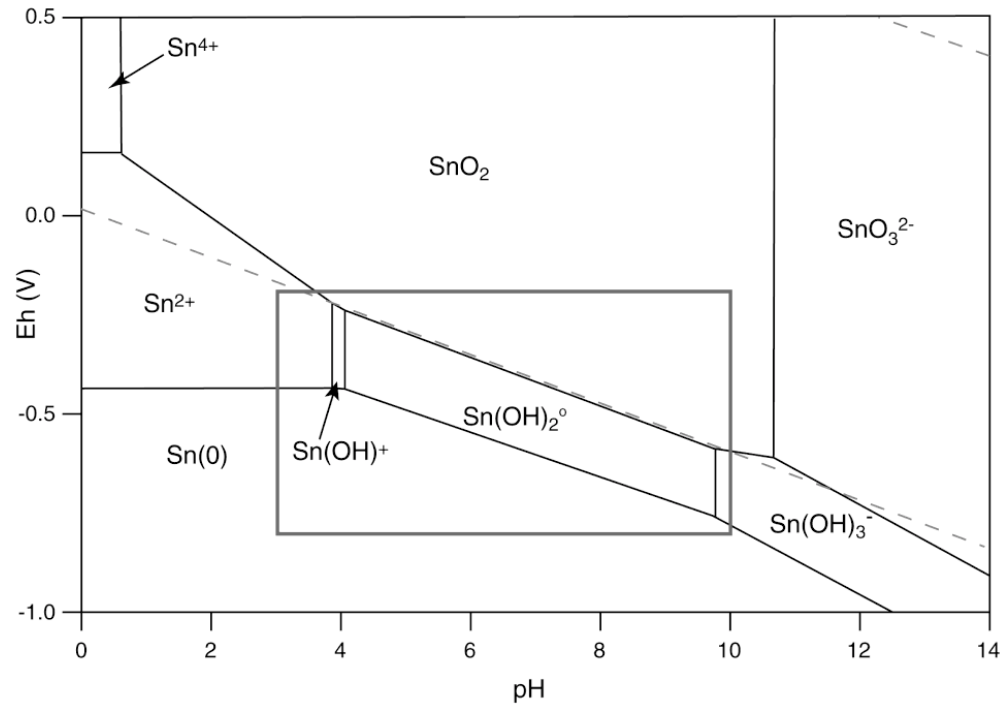

Fig. 7. The system $\mathrm{Sn}-\mathrm{O}-\mathrm{H}_{2} \mathrm{O}$ at standard state with a dissolved tin activity of $10^{-10}$ (Séby et al. 2001). Dashed lines represent the stability field of water. The box represents the area shown in Figure 9.

FIG. 5. Back-scattered-electron images of corrosion phases on a polished cross section of pewter artifacts. The boxes are areas represented in images at higher magnification. (a) FN-457, (b) FN-340. 


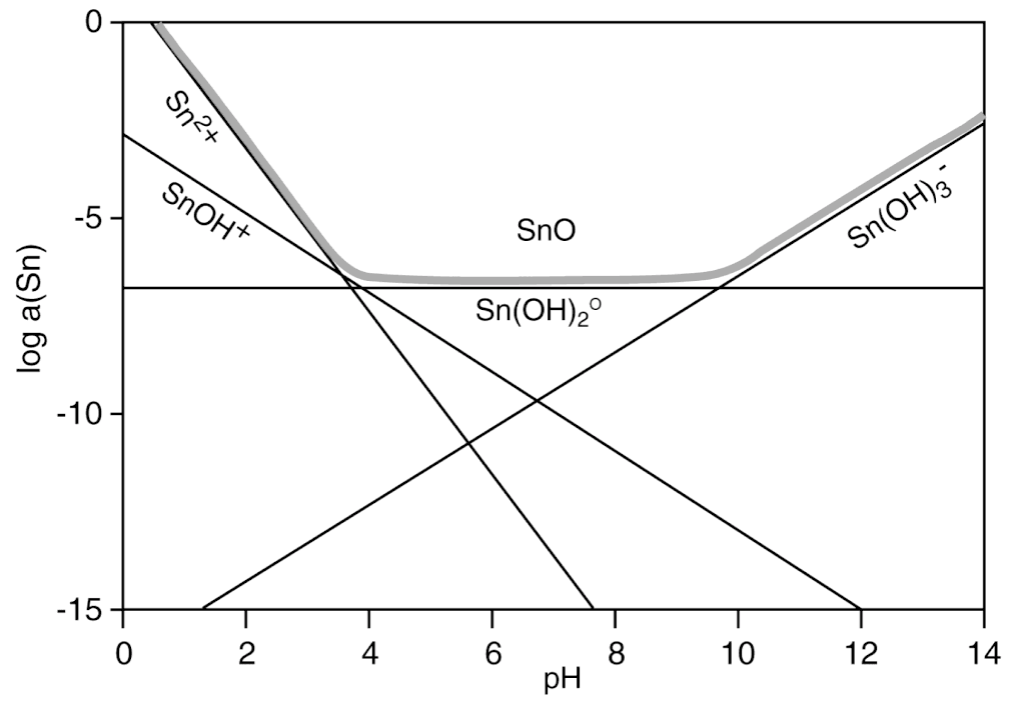

FIG. 8. Distribution of hydrolysis products in a solution saturated with $\mathrm{SnO}(\mathrm{s})$ (Séby et al. 2001).

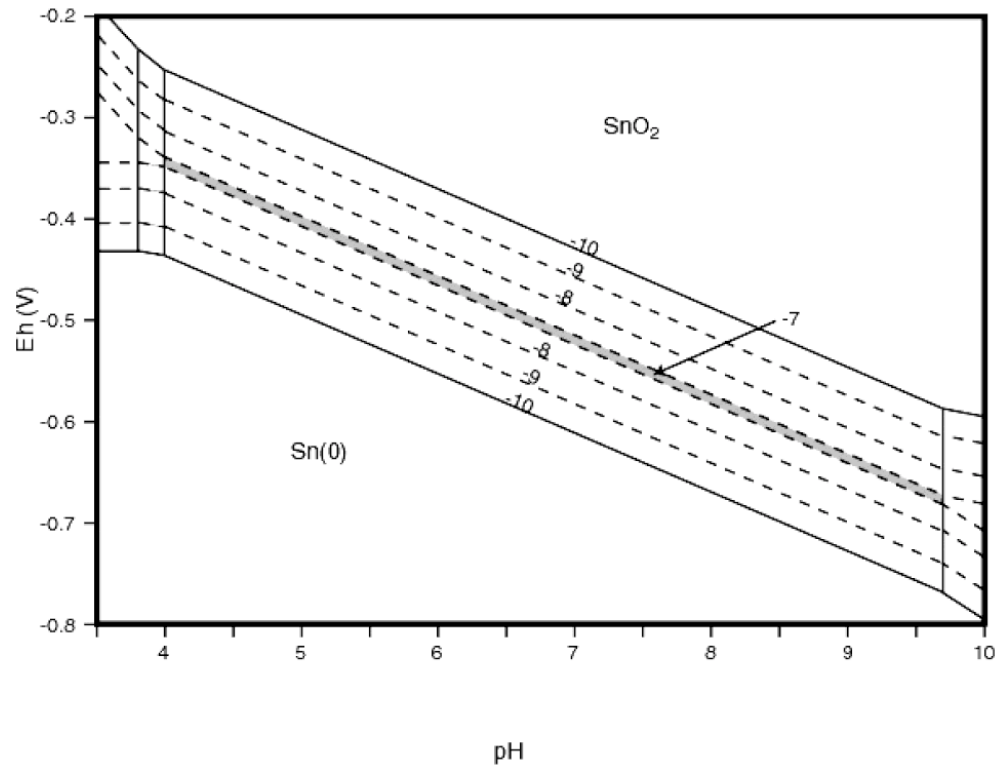

FIG. 9. Expanded view of $\mathrm{Sn}(\mathrm{OH})_{2}{ }^{\circ}$ field from Figure 7. The contours represent the log of the aqueous tin activity. The shaded region is the stability field of $\mathrm{Sn}(\mathrm{OH})_{2}{ }^{0}$ at a dissolved tin activity of $10^{-7}$. 
corrosive elements and the nature of the corrosion minerals that result. Although the corrosion phases are normally viewed as a nuisance in the field of archeology, they actually protect artifacts from further deterioration. Their presence can also provide insight into the processes of tin corrosion that cannot be determined accurately in a normal time-frame in the laboratory. For example, romarchite, little known before this study, has been observed on every pewter artifact from this wreck site where the corrosion products were left intact. Dunkle (2002) extended this study to artifacts from five other shipwrecks on the eastern seaboard of North America and the Caribbean Sea to determine how widespread the occurrence of romarchite is on corroding pewter in seawater. Unpublished results suggest that romarchite, hydroromarchite and abhurite are much more widespread than previously believed. As more is learned about the nature of tin corrosion and metal oxidation in general, the understanding of how these phases serve as a buffer between the reduced metal and the oxidizing natural environment can benefit not only archeologists in their quest to preserve the physical evidence of our history, but may also have wider industrial applications.

\section{ACKNOWLEDGEMENTS}

We thank the Underwater Archaeology Branch of the North Carolina Department of Cultural Resources for permitting access to samples and encouraging the detailed study of the materials. We gratefully acknowledge assistance of Robert Tracy and Gretchen Benedix in electron microprobe and SEM analyses, Ross Angel in X-ray-diffraction analyses, and Andy Roberts with microdiffraction analyses. We appreciate editorial assistance from Mati Raudsepp and Robert F. Martin and the helpful reviews of J.A. Mandarino and A.C. Roberts. We thank Robert A. Ramik for allowing us to read an early draft of the accompanying manuscript while it was undergoing final modification. S. Dunkle thanks the Horton Foundation for providing financial support for travel related to this research.

\section{REFERENCES}

Abrahams, I., Grimes, S.M., Johnston, S.R. \& KnOwLes, J.C. (1996): Tin (II) oxyhydroxide by X-ray powder diffraction. Acta Crystallogr. C52, 286-288.

Chung, Y.S., Hubenko, A., Meyering, L., Schade, M., ZiMMER, J. \& REMMEL, T. (1997): Morphology and phase of tin oxide thin films during their growth from metallic tin. J. Vac. Sci. Technol. A15, 1108-1112.

Craig, J.R., Callahan, J.E., Miller, J.W. \& Lusardi, W.R. (2001): Preliminary studies of some base and precious metals from the Queen Anne's Revenge. Southeastern Geology 40, 41-48.

\& VAughan, D.J. (1994): Ore Microscopy and Ore Mineralogy. John Wiley and Sons, New York, N.Y. (434).

DuNKLE, S.E. (2002): Romarchite and Other Corrosion Phases on Metal Artifacts from the Queen Anne's Revenge (1718). M.S. thesis, Virginia Polytechnic and State University, Blacksburg, Virginia.

Edwards, R., Gillard, R.D. \& Williams, P.A. (1992): The stabilities of secondary tin minerals: abhurite and its relationships to Sn (II) oxides and oxyhydroxides. Mineral. Mag. 56, 221-226.

HATCHER, J. \& BARKer, T.C. (1974): A History of British Pewter. Longman Group Ltd., London, U.K.

LAWRENCE, R.S. \& WILDE-RAMSING, M. (2001): In search of Blackbeard: historical and archaeological research at shipwreck site 0003BUI. Southeastern Geology 40, 1-10.

LUSARDI, W.R. (2000): The Beaufort Inlet shipwreck project. Int. J. Naut. Archeol. 29, 57-68.

Matzko, J.J., Evans, H.T., JR., Mrose, M.E. \& Aruscavage, P. (1985): Abhurite, a new tin hydroxychloride mineral, and a comparative study with a synthetic basic tin chloride. Can. Mineral. 23, 233-240.

NoRTH, N.A. (1987): Conservation of metals. In Conservation of Marine Archaeological Objects. Butterworths, London, U.K.

ORgan, R.M. \& MANDARINO, J.A. (1971): Romarchite and hydroromarchite, two new stannous minerals. Can. Mineral. 10, 916 (abstr.).

RAMiK, R.A., ORgan, R.M. \& Mandarino, J.A. (2003): On type romarchite and hydroromarchite from Boundary Falls, Ontario, and notes on other occurrences. Can. Mineral. 41, 649-657.

Séby, F., Potin-Gautier, M., Giffault, E. \& Donard, O.F.X. (2001): A critical review of thermodynamic data for inorganic tin species. Geochim Cosmochim. Acta 65, 30413053 .

Williams, W., Sarin, P., Wang, C. \& Wisseman, S. (1998): Interpretation of black surface of ancient Chinese bronze mirrors. Abstr. of Presentations, $31^{\text {st }}$ Int. Symp. on Archaeometry (Budapest).

Wilson, M., Madden, P.A., Peebles, S.A. \& Fowler, P.W. (1996): Cation polarization and the crystal structure of SnO. Molecular Phys. 88, 1143-1153.

Received August 2, 2002, revised manuscript accepted May 12, 2003. 